\title{
Sexual orientation and quality of life of people living with HIV/Aids
}

\author{
Orientação sexual e qualidade de vida de pessoas vivendo com HIV/aids \\ Orientación sexual y calidad de vida de personas viviendo con VIHISIDA
}

\section{Francisco Braz Milanez Oliveira', Artur Acelino Francisco Luz Nunes Queiroz", Álvaro Francisco Lopes de Sousa", Maria Eliete Batista Moura', Renata Karina Reis"}

\begin{abstract}
'Universidade Federal do Piauí, Health Sciences Center, Postgraduate Program in Nursing. Teresina, Piauí, Brazil. "Universidade de São Paulo, Ribeirão Preto College of Nursing, Postgraduate Program in Fundamental Nursing. Ribeirão Preto, São Paulo, Brazil.
\end{abstract}

How to cite this article:

Oliveira FBM, Queiroz AAFLN, Sousa AFL, Moura MEB, Reis RK. Sexual orientation and quality of life of people living with HIV/Aids. Rev Bras Enferm [Internet]. 2017;70(5):1004-10. [Thematic Edition "Good practices and fundamentals of Nursing work in the construction of a democratic society"] DOI: http://dx.doi.org/10.1590/0034-7167-2016-0420

\begin{abstract}
Objective: To analyze whether sexual orientation affects the quality of life of people living with HIV/Aids (PLWHA). Method: A crosssectional analytical study was carried out with 146 PLWHA in Teresina, capital city of the state of Piauí, in 2013, by means of the WHOQOL-HIV-bref. Descriptive analysis and multiple linear regression were used for data analysis. Results: There was a prevalence of men $(63.7 \%)$, non-heterosexual (57.0\%), aged between 19 and 39 years (89\%). Of the total, $75.5 \%$ mentioned presence of negative feelings, such as fear and anxiety, and 38\% reported have suffered stigma. With regard to the dimensions investigated, the most affected were "environment" and "level of independence". Non-heterosexual orientation was negatively associated with quality of life in almost all dimensions. Conclusion: Living with HIV/Aids and having a non-heterosexual orientation have a negative impact on quality of life. Descriptors: HIV; Acquired Immunodeficiency Syndrome; Quality of Life; Sexual Orientation; Sexual Minorities.
\end{abstract}

\section{RESUMO}

Objetivo: Analisar se a orientação sexual afeta a qualidade de vida de pessoas vivendo com HIV/aids (PVHAs). Método: Estudo analítico, transversal, realizado com 146 PVHAs em Teresina, PI, no ano de 2013, por aplicação da escala WHOQOL HIVbref. Para análise dos dados, utilizou-se análise descritiva e regressão linear múltipla. Resultados: Houve predominância de homens $(63,7 \%)$, não-heterossexuais $(57,0 \%)$, com idade entre 19 e 39 anos (89\%). Do total, 75,5\% mencionaram presença de sentimentos negativos como medo e ansiedade e 38\% informaram terem sofrido estigma. Com relação aos domínios investigados, os mais comprometidos foram "meio ambiente" e "nível de independência". A orientação não-heterossexual associou-se negativamente à qualidade de vida em, praticamente, todos os domínios. Conclusão: Viver com HIV/aids e ter uma orientação não-heterossexual tem impacto negativo na qualidade de vida.

Descritores: HIV; Síndrome de Imunodeficiência Adquirida; Qualidade de Vida; Orientação Sexual; Minorias Sexuais.

\section{RESUMEN}

Objetivo: Analizar si la orientación sexual afecta la calidad de vida de personas viviendo con VIH/SIDA (PVHAs). Método: Estudio analítico, transversal, realizado con 146 PVHAs en Teresina, PI, durante 2013, mediante aplicación de escala WHOQOL HIVbref. Datos analizados por análisis descriptivo y regresión lineal múltiple. Resultados: Hubo predominio de hombres (63,7\%), no heterosexuales (57,0\%), con edad de 19 a 39 años (89\%). Del total, 75,5\% refirió presencia de sentimientos negativos como miedo y ansiedad, y $38 \%$ reportó haber sufrido estigmatización. Respecto a los dominios investigados, los más comprometidos fueron: "medio ambiente" y "nivel de independencia". La orientación no heterosexual se asoció negativamente a la calidad de vida en prácticamente todos los dominios. Conclusión: Vivir con VIH/SIDA y tener orientación no heterosexual impacta negativamente en la calidad de vida. Descriptores: Síndrome de Inmunodeficiencia Adquirida; Calidad de Vida; Conducta Sexual; Minorías Sexuales. 


\section{INTRODUCTION}

Global surveillance of HIV/Aids is associated with the understanding of regional differences and specificities, as well as epidemiological characteristics and standards that will contribute to propose the creation of effective interventions ${ }^{(1)}$.

In spite of the heterogeneity observed in the population in general, studies show large groups of vulnerability inside this global epidemic, such as the population of men who have sex with men, sex workers, and population deprived of freedom, which are segments often marginalized in societies ${ }^{(2-3)}$.

In Brazil, where high rates of incidence are found ${ }^{(3)}$, universal access to antiretroviral therapy provided a change in the perception of the disease, which changed its status from a fatal disease to a chronic health condition ${ }^{(4)}$. Access to treatment, good adherence to antiretroviral therapy and an increase in diagnosis have caused impacts on the quality of life of these people, leading to an increase in survival time, reduction in morbidity and mortality, increase in life expectancy, and redefinition of future projects ${ }^{(5)}$.

Currently, living with HIV, requires much more than treating the disease. People living with HIV/Aids (PLWHA) often have to deal with transdisciplinary problems that involve depressive symptoms, stigma, discrimination, and the adverse effects of the therapeutic treatment ${ }^{(6-8)}$.

In addition, prejudice associated with sexual orientation is a potential challenge, because AIDS is still a serious problem in the daily life of homosexuals. Collectively, homosexuals, especially men, still bear the social representation of villains and victims of this disease, making them suffer from stigma and prejudice ${ }^{(9)}$.

According to the International Lesbian, Gay, Bisexual, Trans and Intersex Association, being homosexual is considered a crime in 73 countries, and, in at least 13 of them, the punishment for this crime is the death penalty, and 37 of these countries have the highest rates of new infections by HIV in the world ${ }^{(10)}$. Although not being included in this list, Brazil presents a contrast between the image of a tolerant and openminded society and increasing manifestations of prejudice and discrimination against homosexuals, which have been an obstacle for the construction of positive identities and life projects that lead to a less traumatic existence for these people.

Studies show that sexual orientation may influence the quality of life of people living with HIV/Aids, although they do not explore the theme with the depth required. Studies often go beyond findings, supporting them by means of crosschecking among sociodemographic variables, rather than correlating them to dimensions of quality of life $\mathrm{f}^{(7-8)}$.

The aspects mentioned highlight the importance of evaluating the quality of life of people living with HIV, associating it with sexual orientation. The objective of the present study was to analyze whether sexual orientation affects the quality of life of PLWHA.

\section{METHOD}

\section{Ethical aspects}

The development of this study met national and international ethical principles on research involving human beings and was approved by a research ethics committee. The objectives of the study and the free and informed consent form used were presented at the time of data collection.

\section{Study design, setting and population}

This was a cross-sectional analytical study carried out in the specialized care service of an integrated healthcare center, in a capital city in the Northeast region of Brazil.

The study sample was made up of 146 people living with HIV, selected by means of the stratified random sampling method from a universe of 790 people monitored by the abovementioned service and who met the following inclusion criteria: individuals of both genders, aged 18 years or older; with result of serological examination reagent for HIV, having developed the syndrome or not; using antiretroviral therapy; being domiciled in the studied city; presenting conditions to be interviewed and agreeing to participate in the study. Exclusion criteria were: individuals deprived of freedom and with cognitive difficulties.

The participants were approached after their routine consultation by two researchers duly trained. The objectives of the study were presented to the participants and they were free to express their interest in participating in the study or not. Data were collected in a private room of the service through interviews, from August to December 2014, by means of a questionnaire for socioeconomic, demographic, epidemiological, and clinical evaluation of the participants; and an instrument previously translated and validated for Portuguese language - the World Health Organization Quality of Life (WHOQOL) HIV-bref scale, used to measure parameters of quality of life, specific for PLWHA.

\section{Analysis of results and statistics}

The Statistical Package for the Social Sciences 20 (SPSS) was used for data analysis. For the characterization of the population of the study (univariate analysis), descriptive analysis was carried out through means and standard deviations for quantitative variables; and through proportions, for qualitative variables. Socioeconomic, demographic, epidemiological, and clinical variables associated with HIV were presented through the use of distributions of univariate frequencies and descriptive measurements. For data analysis, sexual orientation was dichotomized into heterosexuals and non-heterosexuals (homosexuals and bisexuals).

Reliability analysis of the questionnaire WHOQOL-HIV-bref was carried out by means of the Cronbach's alpha coefficient. The calculation of the scores was carried out following the syntax proposed by the WHOQOL Group. In the final model of analysis, by means of multiple linear regression, the socioeconomic, demographic, epidemiological, and clinical variables were dichotomized and transformed into indicating variables (dummy), adopting the stepwise forward modeling, statistical significance fixed at 5\% ( $\leq$ 0.05) and a 95\% confidence interval.

\section{RESULTS}

Of the 146 people living with HIV/Aids, 63.7\% were men, with a mean age of 38 years. Of the total of participants, $61 \%$ were in the age group of 19 to 39 years, and $67 \%$ did not have 
partners. It was observed that $76 \%$ of the population studied had complete high school or higher education (more than eight years of education), $76 \%$ were non-white, $56.8 \%$ reported being religious non-practitioners, and $39.4 \%$ had an occupation with individual income higher than one minimum wage.

With regard to sexual orientation, $57 \%$ of the men reported being homosexuals/bisexuals and $86.8 \%$ of the women reported being heterosexuals ( $p<0.001)$. Statistical difference was found among sexual orientation, gender, age group, and education level $(p<0.001)$ (Table 1).

Regarding habits and life style (Table 2), 77 (52.7\%) of the PLWHA reported not practicing physical activity, 132 (90.4\%) were alcohol consumers, and 91 (62.3\%) were smokers. In addition, $98(67.1 \%)$ reported not using illicit drugs, $111(76 \%)$ mentioned presence of negative feelings, such as fear and anxiety ( $p=0.027)$, and $56(38.3 \%)$ individuals reported having suffered stigma.

A difference was observed between "physical" ( $p=0.018)$ and "environment" ( $p=0.024)$ dimensions in the non-heterosexual group, whose mean scores of quality of life were lower when compared with the heterosexual group (Table 3).

The regression model that used sexual orientation as a dependent variable allowed to estimate the impact of groups on the main dimensions. In the multivariate analysis (Table 4), nonheterosexual orientation was associated negatively with quality of life in all dimensions, except spirituality, religiosity, and personal beliefs. The variables that most contributed to explain positively, by order of influence, were physical and psychological dimensions $(\mathrm{p}<0.001)$.

Table 1 - Socioeconomic and demographic characteristics of people living with HIV/Aids according to sexual orientation ( $\mathrm{N}=$ 146), Teresina, Piauí, Brazil, 2013

\begin{tabular}{|c|c|c|c|c|c|c|c|}
\hline & \multicolumn{4}{|c|}{ Sexual orientation } & \multirow{2}{*}{\multicolumn{2}{|c|}{ Total }} & \multirow{3}{*}{$p$ value* } \\
\hline & \multicolumn{2}{|c|}{ Non-heterosexual } & \multicolumn{2}{|c|}{ Heterosexual } & & & \\
\hline & $\mathbf{n}$ & $\%$ & $\mathbf{n}$ & $\%$ & $\mathbf{n}$ & $\%$ & \\
\hline Gender & & & & & & & $<0.001$ \\
\hline Male & 53 & 57.0 & 40 & 43.0 & 93 & 100.0 & \\
\hline Female & 07 & 13.2 & 46 & 86.8 & 53 & 100.0 & \\
\hline Age group & & & & & & & $<0.001$ \\
\hline 19-39 years & 48 & 53.9 & 41 & 46.1 & 89 & 100.0 & \\
\hline $40-59$ years & 11 & 22.9 & 37 & 77.1 & 48 & 100.0 & \\
\hline$\geq 60$ years & 01 & 11.1 & 08 & 88.9 & 09 & 100.0 & \\
\hline Current affective relationship & & & & & & & 0.091 \\
\hline With partner & 45 & 45.9 & 53 & 54.1 & 98 & 100.0 & \\
\hline Without partner & 15 & 31.2 & 33 & 68.8 & 48 & 100.0 & \\
\hline Education level & & & & & & & $<0.001$ \\
\hline Up to complete elementary school & 13 & 20.3 & 51 & 79.7 & 64 & 100.0 & \\
\hline High school or + & 47 & 53.7 & 35 & 42.7 & 82 & 100.0 & \\
\hline Race/Skin color & & & & & & & 0.303 \\
\hline White & 17 & 48.6 & 18 & 51.4 & 35 & 100.0 & \\
\hline Non-white & 43 & 38.7 & 68 & 61.3 & 111 & 100.0 & \\
\hline Religion & & & & & & & 0.763 \\
\hline Practitioner & 25 & 39.7 & 38 & 60.3 & 63 & 100.0 & \\
\hline Non-practitioner & 35 & 42.2 & 48 & 57.8 & 83 & 100.0 & \\
\hline Occupation & & & & & & & 0.743 \\
\hline With occupation & 42 & 42.0 & 58 & 58.0 & 58 & 100.0 & \\
\hline Without occupation & 18 & 39.1 & 28 & 60.9 & 46 & 100.0 & \\
\hline Household income & & & & & & & 0.698 \\
\hline Up to one MW & 06 & 46.2 & 07 & 53.8 & 13 & 100.0 & \\
\hline$\geq$ one $\mathrm{MW}$ & 54 & 40.6 & 79 & 59.4 & 133 & 100.0 & \\
\hline Individual income & & & & & & & 0.409 \\
\hline With income & 47 & 39.5 & 72 & 60.5 & 119 & 100.0 & \\
\hline Without income & 13 & 48.1 & 14 & 51.9 & 27 & 100.0 & \\
\hline
\end{tabular}

Note: MW: Minimum wage (R\$678.00); *Pearson's Chi-square test. 
Table 2 - Data associated with habits and life style, presence of fear/anxiety, and stigma in people living with HIV/Aids according to sexual orientation $(\mathrm{N}=146)$, Teresina, Piauí, Brazil, 2013

\begin{tabular}{|c|c|c|c|c|c|c|c|}
\hline & \multicolumn{4}{|c|}{ Sexual orientation } & \multirow{2}{*}{\multicolumn{2}{|c|}{ Total }} & \multirow{3}{*}{$p$ value* } \\
\hline & \multicolumn{2}{|c|}{ Non-heterosexual } & \multicolumn{2}{|c|}{ Heterosexual } & & & \\
\hline & $\mathbf{n}$ & $\%$ & $\mathbf{n}$ & $\%$ & $\mathbf{n}$ & $\%$ & \\
\hline Practice of physical activity & & & & & & & 0.580 \\
\hline Yes & 30 & 43.5 & 39 & 56.5 & 69 & 100.0 & \\
\hline No & 30 & 39.0 & 47 & 61.0 & 77 & 100.0 & \\
\hline Alcohol consumption & & & & & & & 0.200 \\
\hline Drinks or already drank & 52 & 39.4 & 80 & 60.6 & 132 & 100.0 & \\
\hline Does not drink & 08 & 57.1 & 06 & 42.9 & 14 & 100.0 & \\
\hline Smoking & & & & & & & 0.366 \\
\hline Smokes or already smoked & 40 & 44.0 & 51 & 56.0 & 91 & 100.0 & \\
\hline Does not smoke & 20 & 36.4 & 35 & 63.6 & 55 & 100.0 & \\
\hline Use of illicit drugs & & & & & & & 0.241 \\
\hline Uses or already used & 23 & 47.9 & 25 & 52.1 & 48 & 100.0 & \\
\hline Does not use & 37 & 37.8 & 61 & 62.2 & 98 & 100.0 & \\
\hline Presence of fear/anxiety & & & & & & & 0.027 \\
\hline Yes & 40 & 36.0 & 71 & 64.0 & 111 & 100.0 & \\
\hline No & 20 & 57.1 & 15 & 42.9 & 35 & 100.0 & \\
\hline Suffered stigma & & & & & & & 0.996 \\
\hline Yes & 23 & 41.1 & 33 & 58.9 & 56 & 100.0 & \\
\hline No & 37 & 41.1 & 53 & 58.9 & 90 & 100.0 & \\
\hline
\end{tabular}

Note: *Pearson's Qhi-square test.

Table 3 - Distribution of scores of quality of life according to sexual orientation of people living with HIV/Aids ( $\mathrm{N}=146)$, Teresina, Piauí, Brazil, 2013

\begin{tabular}{lccccccc}
\hline & \multicolumn{7}{c}{ Sexual orientation } \\
\cline { 2 - 6 } WHOQOL-HIV-bref & \multicolumn{3}{c}{ Non-heterosexual } & & Heterosexual & \multirow{2}{*}{$\boldsymbol{p}$ value* } \\
\cline { 2 - 6 } & Mean & SD & Median & Mean & SD & Median \\
\hline Physical & 57.8 & 23.2 & 56.3 & 65.8 & 17.5 & 68.8 & 0.018 \\
Psychological & 64.7 & 20.4 & 70.0 & 70.2 & 15.6 & 70.0 & 0.115 \\
Level of independence & 52.2 & 17.6 & 56.3 & 57.1 & 13.6 & 56.3 & 0.161 \\
Social relationships & 62.4 & 19.2 & 62.5 & 66.8 & 19.2 & 68.8 & 0.162 \\
Environment & 44.6 & 17.5 & 45.3 & 50.9 & 13.8 & 50.0 & 0.024 \\
SRPB & 65.8 & 22.5 & 68.8 & 65.6 & 23.6 & 68.8 & 0.998 \\
Overall & 62.9 & 20.7 & 62.5 & 65.0 & 19.8 & 62.5 & 0.483 \\
\hline
\end{tabular}

Note: SD: Standard deviation; SRPB: Spirituality, religiosity, and personal beliefs; *Mann-Whitney test.

Table 4 - Analysis of multiple linear regression adjusted of quality of life of people living with HIV/Aids according to sexual orientation ( $N=146)$, Teresina, Piauí, Brazil, 2013

\begin{tabular}{lcccc}
\hline WHOQOL-HIV-bref & $\beta$ & Cl 95\%(ß) & $\boldsymbol{p}$ value & $\mathbf{r}^{\mathbf{2}} \mathbf{a}$ \\
\hline Physical & -14.96 & $-22.41 ;-7.51$ & $<\mathbf{0 . 0 0 1}$ & 0.180 \\
Psychological & -12.44 & $-18.99 ;-5.89$ & $<\mathbf{0 . 0 0 1}$ & 0.177 \\
Level of independence & -7.93 & $-13.86 ;-1.99$ & 0.009 & 0.104 \\
Social relationships & -10.27 & $-17.73 ;-2.82$ & 0.007 & 0.086 \\
Environment & -8.12 & $-14.29 ;-1.95$ & 0.010 & 0.056 \\
SRPB & -7.00 & $-15.86 ; 1.86$ & 0.121 & 0.103 \\
Overall & -10.25 & $-17.79 ;-2.71$ & 0.008 & 0.145
\end{tabular}

Note: SRPB: Spirituality, religiosity, and personal beliefs; Dependent variable: Non-heterosexual; $\beta$ : Adjusted standardized regression coefficient; r2a: Adjusted correlation coefficient; CI 95\%: 95\% confidence interval. 


\section{DISCUSSION}

The presence of negative feelings, such as fear and anxiety, and having suffered stigma, affect negatively the quality of life of non-heterosexual PLWHA, reduce self-esteem, social support, access to healthcare services and adherence to medication, maximizing risky sexual behaviors and associated vulnerabilities.

In the present study, the socioeconomic, demographic, epidemiological, and clinical profile of the participants evidenced a prevalence of the male gender $(63.7 \%)$ and young adults with a mean age of 38.4 years. Younger homosexual/ bisexual men tend to have a better disposition to deal with the stigma associated with "being gay" when compared to older men, due to the increase in support services in comparison to 20 or 30 years ago, which may influence scores in the evaluation of quality of life $\mathrm{e}^{(11-12)}$.

Men who have sex with men are at a greater risk of infection by HIV when compared to heterosexual men. Once with HIV, the stigma tends to be more present and increases the identity of a "socially devaluated group". The prejudice associated with not being heterosexual still restricts the public visibility of men who have sex with men and keeps them hidden from governmental prevention efforts, either due to fear of discrimination or physical harm due to the disclose of their identities or sexual behavior ${ }^{(12-14)}$.

Stigma to people living with the HIV/Aids may range among countries and even within each of them. ${ }^{13}$ In all cases, this stigma is associated with fewer opportunities for HIV diagnosis, due to social invisibility, lower access to services, and less steady sexual partners. However, there is a greater presence of unmet human needs, risky sexual behaviors, multiples sexual partners, and low rate of use of services ${ }^{(11-14)}$.

Suffering stigma and prejudice contributes to the increase in rates of new infections by HIV, especially due to new possibilities provided by the Internet. In countries where the search for partnerships online, by means of sites such as Facebook or mobile applications, has become more popular, the rates of stigma seem to be higher, since casual sex with partners met online is more present and constant ${ }^{(14-15)}$.

Among the dimensions of quality of life affected, "environment" proved to be impaired in both groups (heterosexuals and non-heterosexuals). This finding may be explained by the homogeneity of the group, either regarding socioeconomic factors, or regarding its access to healthcare services, financial resources, and physical environment. The fact that the sample inhabits in the same city, uses the same healthcare service, and is exposed to the same physical stress (temperature, pollution, and noise) can explain the similarity in the results, even if these two groups have different social backgrounds.

Another dimension similarly impaired in the two groups was the "level of independence", which evaluates work capacity, daily activities, and other questions. The debilitating aspects of the infection by HIV, as well as collateral effects of the highly active antiretroviral therapy (HAART), seem to exert greater influence on this dimension than the spectrum of sexuality. This is due to the fact that the constant infection by the virus may cause muscular inflammation, as well as reduction in pulmonary and cardiac functions ${ }^{(16)}$. The high toxicity of the medications that compose the HAART may cause fatigue, loss of appetite and energy, as well as damage hepatic functions. These effects may have been maximized among the group of heterosexuals of the sample, because these had higher levels of sedentary life style $(52 \%)$, smoking $(62 \%)$, and alcoholism $(90 \%)^{(6)}$.

Among the users, regardless of their sexuality, a great impact of the presence of fear and anxiety was found on quality of life. However, these feelings are closely associated with the HIV diagnosis and the expression of their affective-sexual relationships, and, in spite of advances in the antiretroviral therapy, infection by HIV and Aids are still seen as a disease that is stigmatized, mortal, and worthy of fear ${ }^{(12)}$.

This fear restricts the forms of affective-sexual relationships, confining sexuality for fear of exposing themselves to others, causing forced distancing, anguish, repression, and feelings of denial.

Due to the historical construction of the disease in the LGBT + environment (Lesbian, Gay, Bisexual, Transvestite, Transsexual and Transgender), this condition causes strangeness among heterosexuals who, before being infected, did not perceive themselves at risk. This leads to the concern in hiding their diagnoses, as a form to preserve their personal and social identities, and before the construct of the family ${ }^{(17-18)}$.

However, among the participants with non-heterosexual orientations, living with the possibility of getting infected is present since the moment of discovery or acceptance of their sexuality; which is a fact that allows a greater familiarity with the infection and greater support from the LGBT + community. Because the construct of the "family" is not so strong among this group, there is a greater fear with regard to a possible "divine retribution", due to their behaviors and "reprehensible" life style by most western religions ${ }^{(17-19)}$.

After the adjusted linear regression, the results showed that "physical, psychological, social relationships, level of independence, environment, SRPB, and overall" dimensions were impaired if the participant had a non-heterosexual sexuality. The impacts of a sexuality that is different from a standard imposed and constructed by societies are clearly perceived in manifestations (violent or not) of homophobia, in the denial of basic rights (such as access to healthcare services), in the psychic suffering caused by the invisibility imposed by societies and media to these individuals, and especially in deaths caused by homophobia ${ }^{(19)}$.

A systematic review study evidenced that the risk of depression among LGBT + people is at least twice higher than among heterosexuals. Similarly, LGBT + people are at a higher risk of life and prevalence of anxiety disorders compared to heterosexuals. Stigma, prejudice, and discrimination suffered by LGBT + people promote a hostile and stressing environment that leads to mental health problems ${ }^{(20)}$.

\section{Limitations and contributions to nursing}

The present study has limitations. Most variables of interest, such as sexual orientation, were self-reported. The fact that it was carried out in a state healthcare institution restricts 
the results and these may be influenced by sociocultural factors present in the region. In addition, its cross-sectional design did not allow a follow-up of the participants, which could contribute to establish cause and effect relationships. However, studies of this nature are important for enabling to explore pertinent subjects, such as sexual orientation associated with quality of life, which is little approached in Brazil. In addition, studies of this nature are not found in the Northeast of Brazil, in spite of the high prevalence of HIV/Aids in this region.

The measurement and evaluation of quality of life of PLWHA may contribute to improve nursing care to people who are HIV positive, allowing an individualized and holistic care able to include, in addition to aspects directed to HIV/ Aids and other sexually transmissible diseases, topics associated with the sexuality of these individuals.

\section{CONCLUSION}

Living with HIV/Aids and having a non-heterosexual orientation have a negative impact on quality of life. Being non-heterosexual was negatively associated with the main dimensions of quality of life: physical, psychological, level of independence, social relationships, environment, and overall. The variables that most contributed to explain the dimensions positively were "physical" and "psychological".

The strengthening of individualized and embracing care for this group is necessary, by means of access policies to comprehensive care to the LGBT + population, in order to generate an embracing care and collective environment, free of discrimination or prejudice, promoting the fight against the disease and promotion of quality of life and health.

\section{REFERENCES}

1. Kagotho N, Ssewamala FM. Correlates of depression among caregivers of children affected by HIV/AIDS in Uganda: findings from the Suubi-Maka Family Study. AIDS Care[Internet]. 2012[cited 2016 Aug 03];24(10):1226-32. Available from: http://www.ncbi. nlm.nih.gov/pubmed/22375826

2. Beyrer C. A call to action for comprehensive HIV services for men who have sex with men. Lancet [Internet]. 2012 [cited 2016 Aug 03];380(9839):424-38. Available from: http://www.ncbi.nlm.nih.gov/pubmed/22819663

3. Grangeiro A, Castanheira ER, Nemes MIB. The reemergence of the Aids epidemic in Brazil: Challenges and perspectives to tackle the disease. Interface [Internet]. 2015[cited 2016 Aug 03];19(52):5-8. Available from: http://www.scielo.br/pdf/icse/v19n52/ en_1807-5762-icse-19-52-0005.pdf

4. Campos LN, César CC, Guimarães MD. Quality of life among hiv-infected patients in Brazil after initiation of treatment. Clinics[Internet]. 2009 [cited 2016 Aug 03];64(9):867-75. Available from: http://www.ncbi.nlm.nih.gov/pubmed/19759880

5. Domingues CS, Waldman EA. Causes of death among people living with SIDA in the pre-and pos-HAART eras in the city of São Paulo, Brazil. PLoS ONE[Internet]. 2014[cited 2016 Aug 03];9(12):1-16. Available from: http://journals.plos.org/plosone/ article? $\mathrm{id}=10.1371 \% 2$ Fjournal.pone.0114661

6. Oguntibeju OO. Quality of life of people living with HIV and AIDS and antiretroviral therapy. HIV/AIDS. HIV AIDS (AuckI)[Internet]. 2012[cited 2016 Aug 03];4:117-24. Available from: http://www.ncbi.nlm.nih.gov/pmc/articles/PMC3418767/

7. Oliveira FBM, Moura MEB, Araújo TME, Andrade EMLR. Quality of life and associated factors in people living with HIV/AIDS. Acta Paul Enferm[Internet]. 2015[cited 2016 Aug 03];28(6):510-6. Available from: http://www.scielo.br/pdf/ape/v28n6/en_1982-0194ape-28-06-0510.pdf

8. Emlet CA, Fredriksen-Goldsen KI, Kim HJ. Risk and protective factors associated with health-related quality of life among older gay and bisexual men living with HIV disease. Gerontologist[Internet]. 2013[cited 2016 Aug 03];53(6):963-72. Available from: https:// www.ncbi.nlm.nih.gov/pubmed/23355449

9. Terto Júnior V. Homossexualidade e saúde: desafios para a terceira década de epidemia de HIV/AIDS. Horiz Antrop[Internet]. 2002[cited 2016 Aug 03];8(17):147-58. Available from: http://www.scielo.br/pdf/ha/v8n17/19080.pdf

10. International lesbian, gay, bisexual, trans and intersex association. A map of sexual orientation laws in the world [Internet]. 2016[cited 2016 Aug 03]. Available from: http://ilga.org/downloads/03_ILGA_WorldMap_ENGLISH_Overview_May2016.pdf

11. Halkitis PN, Wolitski RJ, Millett GA. A holistic approach to addressing HIV infection disparities in gay, bisexual, and other men who have sex with men. Am Psychol[Internet]. 2013[cited 2016 Aug 03];68(4):261-73. Available from: http://www.ncbi.nlm.nih. gov/pubmed/23688093

12. Rongkavilit C, Wright K, Chen X, Naar-King S, Chuenyam T, Phanuphak P. HIV stigma, disclosure and psychological distress among Thai youth living with HIV. Int J STD AIDS[Internet]. 2010[cited 2016 Aug 03];21(2):126-32. Available from: http://www. ncbi.nlm.nih.gov/pubmed/20089999

13. Fay H, Baral SD, Trapence G, Motimedi F, Umar E, lipinge S, et al. Stigma, healthcare access, and HIV knowledge among men who have sex with men in Malawi, Namibia, and Botswana. AIDS Behav[Internet]. 2011 [cited 2016 Aug 03];15(6):1088-97. Available from: http://www.ncbi.nlm.nih.gov/pubmed/21153432

14. Pachankis JE, Hatzenbuehler ML, Hickson F, Weatherburn P, Berg RC, Marcus U, et al. Hidden from health: structural stigma, sexual orientation concealment, and HIV across 38 countries in the European MSM Internet Survey. AIDS[Internet]. 2015[cited 
2016 Aug 03];29(10):1239-46. Available from: http://www.ncbi.nlm.nih.gov/pubmed/26035323

15. Marcus U, Hickson F, Weatherburn P, Schmidt AJ. Estimating the size of the MSM populations for 38 European countries by calculating the survey-surveillance discrepancies (SSD) between self-reported new HIV diagnoses from the European MSM internet survey (EMIS) and surveillance-reported HIV diagnoses among MSM in 2009. BMC Public Health[Internet]. 2013 [cited 2016 Aug 03];13:919-31. Available from: http://www.ncbi.nlm.nih.gov/pubmed/24088198

16. Olsen M, Jensen NK, Tesfaye M, Holm L. Conceptual equivalence of WHOQOL-HIV among people living with HIV in Ethiopia. Qual Life Res[Internet]. 2013[cited 2016 Aug 03];22(2):361-7. Available from: http://www.ncbi.nlm.nih.gov/pubmed/22367635

17. Malavé S, Ramakrishna J, Heylen E, Bharat S, Ekstrand ML. Differences in testing, stigma, and perceived consequences of stigmatization among heterosexual men and women living with HIV in Bengaluru, India. AIDS Care[Internet]. 2014[cited 2016 Aug 03];26(3):396403. Available from: http://www.ncbi.nlm.nih.gov/pubmed/23869716

18. Okoror TA, Falade CO, Walker EM, Olorunlana A, Anaele A. Social context surrounding HIV diagnosis and construction of masculinity: a qualitative study of stigma experiences of heterosexual HIV positive men in southwest Nigeria. BMC Public Health[Internet]. 2016[cited 2016 Aug 03];16(1):507. Available from: http://www.ncbi.nlm.nih.gov/pmc/articles/PMC4906588/

19. Barrientos J, Vidal F, Cárdenas M. Homophobia and quality of life among people living with HIV in Chile. Int J Hisp Psychol[Internet]. 2012[cited 2016 Aug 03];5(2):195-205. Available from: https://www.researchgate.net/ publication/298820320_Homophobia_and_quality_of_life_among_people_living_with_HIV_in_Chile

20. King M, Semlyen J, Tai SS, Helen K, Osborn D, Dmitri Popelyuk. A systematic review of mental disorder, suicide, and deliberate self-harm in lesbian, gay and bisexual people. BMC Psychiatry[Internet]. 2008[cited 2016 Aug 03];8:70. Available from: http:// www.ncbi.nlm.nih.gov/pmc/articles/PMC2533652/ 